\title{
Research on entrepreneurship, entrepreneurial bricolage and performance of IT new venture
}

\author{
Zhang Fenghai ${ }^{1}$, Wang Fang ${ }^{2 *}$ \\ ${ }^{1}$ College of management, Dalian Polytechnic University, Dalian, Liaoning Province, 116034, China \\ ${ }^{2}$ College of management, Dalian Polytechnic University, Dalian, Liaoning Province, 116034, China
}

\begin{abstract}
Through the questionnaire survey of 152 IT new ventures, this study establishes the relationship model of entrepreneurship, entrepreneurial bricolage and IT new ventures performance, and uses regression analysis and other methods to obtain the following results: giving full play to entrepreneurship can effectively promote IT new venture to carry out entrepreneurial bricolage; entrepreneurship has a significant impact on IT new venture performance. Entrepreneurial bricolage can effectively improve the IT new venture performance and promote their growth; Entrepreneurial bricolage plays a partial intermediary role between entrepreneurship and IT new venture performance.
\end{abstract}

\section{Introduction}

New venture performance are always the important research area. Although national policies strongly support entrepreneurship, they cannot fundamentally solve the problem of the weak nature of new venture. Bricolage is seen as a third way to deal effectively with resource constraints, in addition to financing and forgoing. Some studies have shown that it can improve frim performance and frim growth.However,bricolage belongs to the operational level of entrepreneurial activities and is influenced by the ideological level of enterprises. As far as the current research is concerned, the most important concept in enterprise consciousness is entrepreneurship. But no studies have been conducted to link entrepreneurship and bricolage to verify the relationship between the three. Therefore, this study selects IT new venture as the research samples, and establishes a theoretical model of entrepreneurial, bricolage and new venture performance to reveal the role path of the three.

\section{Literature review}

Bricolage was first proposed by Lévi-Strauss ${ }^{[1]}$. Later in 2005, Baker and Nelson ${ }^{[2]}$ introduced it into the field of entrepreneurship and proposed Entrepreneurial Bricolage. The entrepreneurial bricolage is defined as: facing new problems and opportunities by combining existing resources. Its main features are not limited to resource attributes, breaking the original resource analysis model, and reassembling and defining resources. It emphasis: 'existing resources', 'immediate action' and 'purposeful resource reconstruction'. It is considered as an effective way to effectively solve the constraints of corporate resources.

Entrepreneurial was first proposed by $\mathrm{Knight}^{[3]}$. It refers to the qualities and talents shown by entrepreneurs in the overall operation of the enterprise. At present, scholars have reached a consensus that entrepreneurship has a significant positive impact on business performance, and most studies have shown that entrepreneurial bricolage has a significant impact on new venture performance. However, the current research has not studied the synergistic relationship between entrepreneurship and entrepreneurial bricolage on the performance of new ventures.

\section{Theoretical analysis and research hypothesis}

It has been recognized that entrepreneurship can have a positive impact on enterprise performance ${ }^{[4][5]}$. Stinchfield ${ }^{[6]}$ found that in the process of starting a business, what entrepreneurs pursue is not profit maximization, but economic return maximization, indicating that the goal of the enterprise is to find a way to maximize the utilization of resources. Baker \& Nelson and other entrepreneurs engaged in bricolage in entrepreneurship refuse to accept the traditionally defined surface value, which is more conducive to the acquisition of external resources for entrepreneurship, but instead participate in entrepreneurial behavior where corporate resources do not match external opportunities. It is proposed that entrepreneurship is not a pure rational system, and to some extent, it affects non-traditional corporate behavior (entrepreneurial bricolage). From the theoretical point of view, it is assumed to have a positive effect. 
Through literature review, it can be inferred that entrepreneurial bricolage can help new venture overcome their inherent deficiencies in resources and information, help enterprises break through unsolvable problems, reduce the risk of failure, and achieve the sustainable growth of enterprises under viable conditions. In summary, the research hypothesis model is constructed as shown in figure 1 .

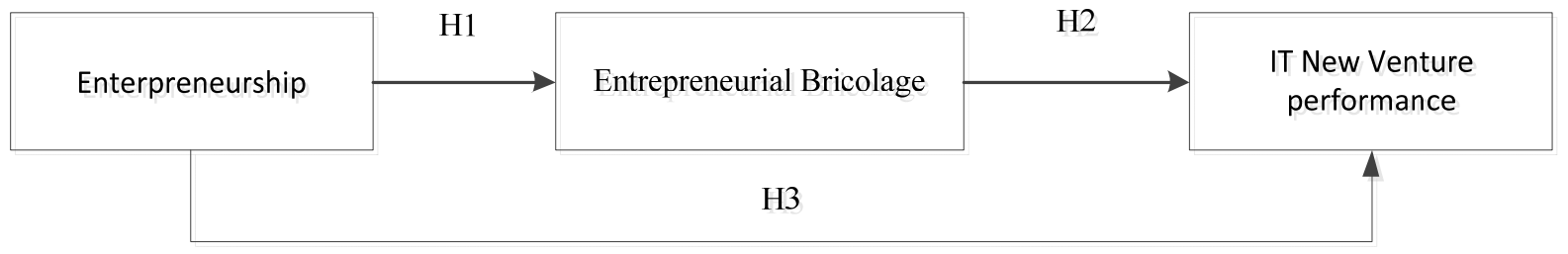

Figure 1. Hypothesis model

\section{Research design and data analysis}

\subsection{Sample description}

IT enterprises established within 8 years were selected based on the research of other domestic scholars. 232 questionnaires and 152 valid samples were collected, with an effective recovery rate of $66 \%$. The questionnaire was sent directly to the manager of the entrepreneurial team, which was relatively representative.
See table $1.78 .9 \%$ of the respondents were male, in line with the current male-female ratio in the IT industry. From the perspective of age, $46.1 \%$ are $21-30$ years old, and $49.3 \%$ are $31-40$ years old. Compared with the survey data of other industries, IT new ventures and entrepreneurs are younger. According to the survey, the education level is generally high, which proves that the technical barriers in IT industry require entrepreneurs to have a sufficient knowledge system and a high level of education. From the perspective of enterprise information, $91.4 \%$ of enterprises with a life of less than 4 years are in the initial stage, and most of them are small and medium-sized enterprises with less than 50 employees.

Table 1. basic information questionnaire

\begin{tabular}{|c|c|c|c|c|c|c|c|}
\hline Name & Category & Frequency & Percentage & Name & Category & Frequency & Percentage \\
\hline \multirow[t]{2}{*}{ Gender } & man & 120 & $78.90 \%$ & \multirow{6}{*}{ Year } & $\begin{array}{c}\text { Following } 1 \\
\text { year }\end{array}$ & 68 & $44.70 \%$ \\
\hline & woman & 32 & $21.10 \%$ & & $1-2$ & 55 & $36.20 \%$ \\
\hline \multirow{4}{*}{ Age } & $\begin{array}{l}20 \text { and the } \\
\text { following }\end{array}$ & 3 & $2.00 \%$ & & $2-4$ & 16 & $10.50 \%$ \\
\hline & $21-30$ & 70 & $46.10 \%$ & & $4-6$ & 7 & $4.60 \%$ \\
\hline & $31-40$ & 75 & $49.30 \%$ & & $6-8$ & 6 & $3.90 \%$ \\
\hline & $41-50$ & 3 & $2.60 \%$ & & 5 and below & 23 & $15.10 \%$ \\
\hline \multirow{4}{*}{ Ed. } & $\begin{array}{c}\text { High } \\
\text { school and } \\
\text { below }\end{array}$ & 1 & $0.70 \%$ & \multirow{4}{*}{ Size } & $6-20$ & 56 & $36.80 \%$ \\
\hline & $\begin{array}{l}\text { Undergradu } \\
\text { ate course }\end{array}$ & 76 & $50.00 \%$ & & $21-50$ & 35 & $23.00 \%$ \\
\hline & master & 68 & $44.70 \%$ & & $51-100$ & 21 & $13.8 \%$ \\
\hline & Dr. & 7 & $4.60 \%$ & & $\begin{array}{l}\text { More than } \\
100\end{array}$ & 17 & $11.2 \%$ \\
\hline
\end{tabular}

\subsection{Reliability and validity analysis}

SPSS18.0 was used to test the reliability and validity of the data. All the measurement items of all variables were extracted and mature scales, and the dimension factor of all variables was greater than 0.7 , as shown in table 2 . It indicates that the variables have good reliability. The KMO values of entrepreneurial spirit, entrepreneurial combination and enterprise performance were 0.844, 0.818 and 0.869 respectively by KMO test and Barlett's sphericity test, and the significance of bartlett's sphericity test factor was 0.000 , indicating that the data was suitable for factor analysis, and the factor load of each item was greater than 0.612 , indicating that the questionnaire had good structural validity. The cumulative variance of each factor is greater than $50 \%$, indicating that variable information can be extracted effectively. 
Table 2. reliability and validity test table

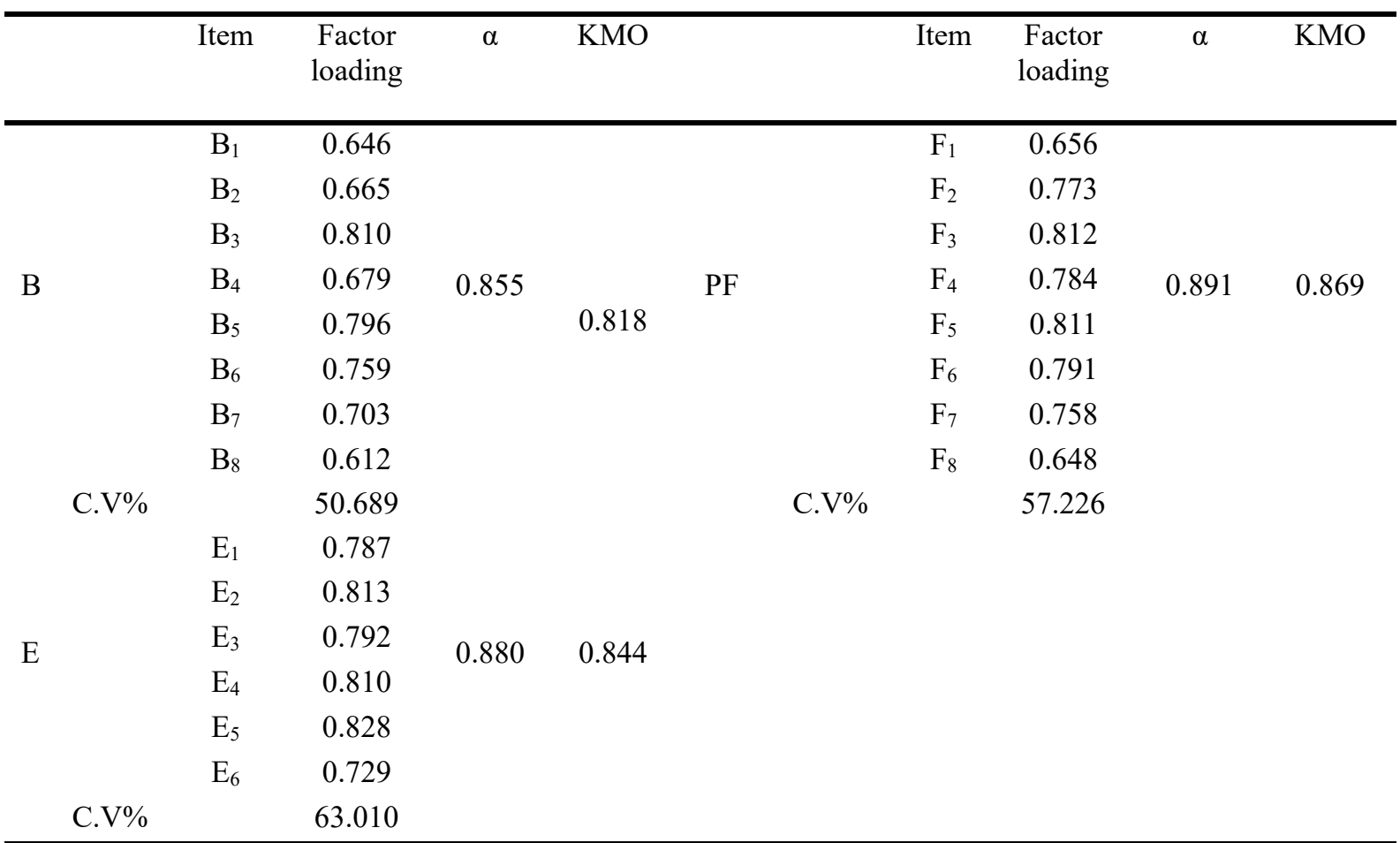

corporate performance $(\mathrm{r}=0.870, \mathrm{p}<0.01)$ and

\subsection{Correlation analysis}

The Person correlation coefficient test was used to test the correlation between the measured variables and the control variables. As shown in table 3, control variable enterprise scale and the entrepreneurial together and measured variables at the 0.01 level significantly related to enterprise performance, and entrepreneurship and entrepreneurship $(r=0.700, p<0.01)$ showed significant correlation, and entrepreneurship together with new venture performance $(\mathrm{r}=0.710, \mathrm{p}<0.01)$ showed a strong correlation between the strong correlation between the variable regression analysis to provide further support.

Table 3. standard deviation and correlation coefficient of variables

\begin{tabular}{cccccccc}
\hline & The mean & s.d & 1 & 2 & 3 & 4 & 5 \\
\hline E & 3.5230 & 0.69213 & 1 & & & & \\
B & 3.7294 & 0.56113 & $0.700^{* *}$ & 1 & & & \\
F & 3.5395 & 0.65837 & $0.870^{* *}$ & $0.710^{* *}$ & 1 & & \\
Year & 1.87 & 1.040 & 0.118 & $0.180^{*}$ & $0.170^{*}$ & 1 & \\
Size & 2.69 & 1.214 & $0.189^{*}$ & $0.292^{* *}$ & $0.267^{* *}$ & $0.518^{* *}$ & 1 \\
\hline
\end{tabular}

\subsection{Regression analysis}

The relationship between variables was tested by stepwise regression analysis, and VIF all less than 2.1, far lower than the threshold value of 10 . The D-W test was performed on model 5, and the test value was 2.101, and the tolerance was both greater than 0.1 , so the possibility of multicollinearity was excluded. As shown in model 1, entrepreneurship has a significant positive impact on entrepreneurial bricolage $(\beta=0.700, p<0.001)$. As shown in model 2, entrepreneurship has a significant positive impact on the performance of IT new ventures $(\beta=0.870, p<0.001)$. As shown in model $3(\beta=0.710$, $\mathrm{p}<0.001$ ), the null hypothesis $\mathrm{H} 3$ is valid. According to the adjusted $\mathrm{R}^{2}$ shown in model 4 and 5 , the value between entrepreneurship and IT new venture performance increased from 0.768 to 0.782 , and the threshold between entrepreneurship and IT new venture performance decreased somewhat and remained significant, indicating that entrepreneurial bricolage played a partial intermediary role between entrepreneurship and IT new venture performance. 
Table 4. regression analysis

\begin{tabular}{cccccc}
\hline \multirow{2}{*}{ variable } & Model1 & Model2 & Model3 & Model4 & Model5 \\
\cline { 2 - 6 } & $\mathrm{B}$ & \multicolumn{4}{c}{$\mathrm{PF}$} \\
\hline year & & & & 0.019 & 0.016 \\
size & & & & $0.097^{*}$ & 0.070 \\
E & $0.700^{* * *}$ & $0.870^{* * *}$ & & $0.849^{* * *}$ & $0.733^{* * *}$ \\
B & & & $0.710^{* * *}$ & & $0.174^{* *}$ \\
$\mathrm{R}^{2}$ & 0.489 & 0.756 & 0.504 & 0.768 & 0.782 \\
Adjust R $^{2}$ & 0.486 & 0.755 & 0.501 & 0.763 & 0.776 \\
\hline
\end{tabular}

\section{Conclusion}

The above studies have concluded that entrepreneurship has a positive promoting effect on the implementation of entrepreneurial piecing for IT new venture and that entrepreneurial bricolage plays a partial intermediary role between entrepreneurship and the performance of IT new venture.

From the perspective of data, the impact of entrepreneurship on the performance of IT new venture in the collaborative process is much higher than bricolage, but the effect of this indirect approach cannot be ignored. The reason why entrepreneurship affects entrepreneurial bricolage is that under resource constraints, people with the spirit of innovation and risk are more willing to adopt unconventional and innovative ways to solve existing problems, which can promote resource breaking and reorganization to solve resource constraints.

Entrepreneurship can effectively promote the strength of IT new venture entrepreneurial bricolage, and realize the new resource establishment process of "discovery, break and reorganization" of resources. Referring to other studies, entrepreneurial behaviors can help shape entrepreneurship. Therefore, there is a two-way relationship between entrepreneurial bricolage and entrepreneurship, which can promote each other, and the coordinated improvement of the two can more effectively help the development of enterprises.

\section{Acknowledgment}

Finally, I would like to thank the schools, teachers, and companies surveyed for supporting this research. Thanks for their support and cooperation.

\section{References}

1. Levi-Strauss C, Wolfram S. (1966) The Savage Mind. J. Nature of Human Society, 35(vember): 157-178.

2. BAKER T, MINER S A, EESLEY T D. (2003) Improvising Firms: Bricolage, Account Giving and Improvisational Competencies in the Founding Process.J. Research Policy, 32(2): 255-276.

3. Knight F H. Risk, Uncertainty and profit. Houghton Mifflin, New York.

4. Peters T J, Waterman R H. (1982) In Search of Excellence[M]. NewYork: Harper and Row, 1982.
5. Xie xueyan, chang qianqian. (2017) Entrepreneurship and performance of high-tech enterprises -- based on new third board information technology enterprises. J. monthly journal of finance and accounting, (03).

6. Stinchfield B T, Nelson R E, Wood M S. (2013) Learning From Levi-Strauss' Legacy: Art, Craft, Engineering, Bricolage, and Brokerage in Entrepreneurship. J. Entrepreneurship Theory and Practice, 37(4): 889-921. 